\title{
Optimization and fabrication of a portable biogas reactor
}

\author{
Abu Yousuf*, Salma Akhter Iqbal, Niloy Chandra Sarker, Md. Nazmul Hasan, \\ Mohammad Shahadat Hussain Sarker \\ Department of Chemical Engineering and Polymer Science, Shahjalal University of Science and \\ Technology, Sylhet-3114, Bangladesh.
}

\begin{abstract}
The study was conducted to investigate the production of biogas from kitchen waste (KW) with co-digestion of cow manure $(\mathrm{CM})$ by using anaerobic digestion process. The experimental protocol was defined to examine the effect of organic loading rate (OLR), temperature, and $\mathrm{NaOH}$-treatment on the efficiency of the production of biogas. A portable biogas reactor was fabricated for efficient biogas production which included an agitation and a heating system. The $\mathrm{KW}$ and CM were co-digested at ratios of 1:1, 2:1, 3:1, 4:1, 5:1, 6:1, 7:1 and 8:1 respectively at loading rates of 50, $100,150,200,250,300,350$, and $400 \mathrm{~g} / \mathrm{L}$. The highest degradation rate of $7.96 \mathrm{ml} / \mathrm{g}$ was obtained from the loading rate of $200 \mathrm{~g} / \mathrm{L}$. Furthermore, $\mathrm{KW}$ was co-digested at different temperatures $25,35,40,45$, and $50^{\circ} \mathrm{C}$, maintaining the same loading rate of $200 \mathrm{~g} / \mathrm{L}$ and the highest degradation rate of $7.98 \mathrm{ml} / \mathrm{g}$ was inspected at temperature $35^{\circ} \mathrm{C}$. The alkali $(\mathrm{NaOH})$ was used to treat $\mathrm{KW}$ to improve biogas production and four $\mathrm{NaOH}$ doses $0.5 \%, 1.0 \%, 1.5 \%$, and $2.0 \%$ on wet matter basis of $\mathrm{KW}$ were applied. The highest degradation rate $13.21 \mathrm{ml} / \mathrm{g}$ was obtained from $1.5 \% \mathrm{NaOH}$ which was almost double compared to untreated KW. In addition, $39.74 \%$ more biogas could be produced from $1.5 \% \mathrm{NaOH}-$ treated KW than untreated KW. The results were further verified by scaling up to a semi-continuously-operating pilotplant reactor co-digesting $\mathrm{KW}$ with $\mathrm{CM}$ as bacterial seed and confirmed that no negative impact was imposed at optimized conditions.
\end{abstract}

\section{INTRODUCTION}

Disposal of municipal solid waste (MSW) is a major concern in large cities of Bangladesh. Kitchen waste, which is defined as the food residuals generated from restaurants, cafeterias, student dormitories, hotels, and households etc, is a main organic fraction of MSW. Anaerobic digestion of organic waste to produce biogas has been regarded as an attractive technology of treating waste biomass, for example, agriculture waste, organic fraction of MSW, as well as organic waste from food industry. In terms of high biodegradability of $\mathrm{KW}$, it is a typical organic waste suitable for anaerobic digestion.

Although biodegradable organic matter could be used as sole feedstock in anaerobic digestion, the digestion process tends to fail without the addition of external nutrients and buffering agents [1]. Co-digestion with animal manure or sewage sludge as base feedstock is an effective way to improve buffer capacity and achieve stable performance [2-5]. On the other hand, the addition of readily biodegradable organic matter into animal manure digester could significantly increase biogas production due to the changes of feedstock characteristics. According to another report [6], co-digestion of cattle slurry with fruit and vegetable waste obtained more cumulative biogas production than the digestion of cattle slurry alone. While co-digestion of $\mathrm{KW}$ and $\mathrm{CM}$ was expected to achieve better performance due to the advantages of co-digestion such as more suitable physiochemical characteristics and improved nutrients balance [7].
The prime object of this work was to investigate the prospect of $\mathrm{KW}$ for biogas generation as a renewable energy sources by means of co-digestion with $\mathrm{CM}$ at different ratio in batch experiment, also investigate the effects of OLR, temperature and treatment of KW with $\mathrm{NaOH}$. A portable biogas reactor was also fabricated for efficient biogas production and ultimate goal was to protect the environment from the bad effect MSW in terms of waste to energy.

\section{MATERIALS AND METHODS}

\subsection{Waste collection and processing}

The kitchen wastes used in this study were collected from the student dormitory, residential area of Shahjalal University of Science \& Technology. Cow manures were collected from the village nearby the university. The kitchen waste contains mainly vegetables, non-used vegetable, cooked rice, etc. After removing the bones, metals, chopsticks, plastic bags and inorganic residuals, wastes were cut into small size then they were mashed into pest like substances by using hopper.

\subsection{Experimental Design}

A simple lab- scale experiment was designed using nine digesters which were made of glass. The volume of digester was $1 \mathrm{~L}$ each and working volume was 0.5 L. Each digester was connected with water chamber (plastic bottles) by a plastic pipe (gas pipe) which was used to allow the produced gas to flow through it to the water chamber and hence displaced the same volume of water from the chamber, which was then used to 
flow through another plastic pipe (water pipe) to the water collector. The set up is illustrated in Fig.1.

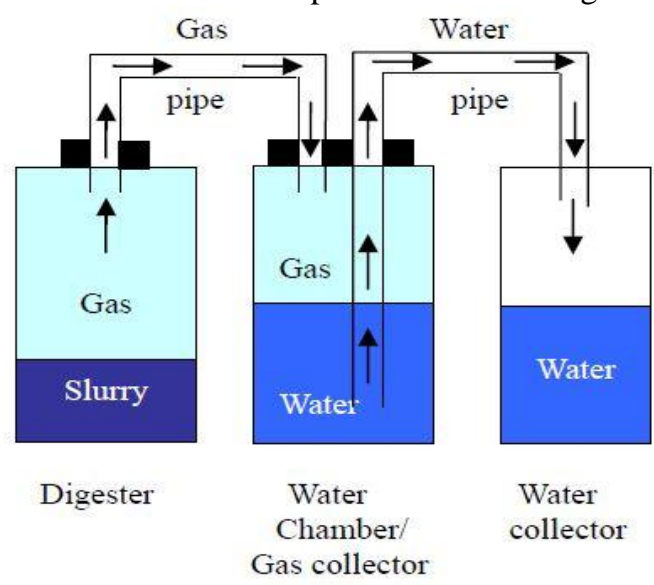

Fig.1: Schematic diagram of the lab-scale experimental set-up. (Adapted from [8]).

\subsection{Anaerobic digester operation}

Lab- scale experiments were operated in batch mode. Firstly we prepared two digesters, D-1.1 and D-1.2 for only $\mathrm{KW}$ and co-digested KW with $\mathrm{CM}$. The digesters were run at room temperature $\left(28-30^{\circ} \mathrm{C}\right)$. The substrate composition of the digesters is shown in the Table-1.

Table-1: Composition of digester for pre-experimental studies

\begin{tabular}{|l|c|c|}
\hline Digester & $\begin{array}{c}\text { Organic biomass, } \\
\mathrm{KW}(\mathrm{g})\end{array}$ & $\begin{array}{c}\text { Bacteria seed, } \\
\mathrm{CM}(\mathrm{g})\end{array}$ \\
\hline $\mathrm{D}-1.1$ & 100 & 00 \\
\hline $\mathrm{D}-1.2$ & 100 & 25 \\
\hline
\end{tabular}

For the subsequent studies, nine digesters were set up as described in the Table-2 maintaing loading rate, mixing ratio and temperature. All digester were put into water bath to maintain temperature. Retention time of digestion was 10- 13 days depending on the gas production. The digestion experiment for each loading rate was triplicate.
Table-2: Digesters specification

\begin{tabular}{|l|c|c|c|c|c|}
\hline Digester & $\begin{array}{c}\text { Mixing } \\
\text { ratio of } \\
\text { KW to } \\
\text { CM }\end{array}$ & $\begin{array}{c}\text { KW } \\
(\mathrm{g})\end{array}$ & $\begin{array}{c}\text { CM } \\
(\mathrm{g})\end{array}$ & $\begin{array}{c}\text { Loading } \\
\text { rate of } \\
\text { KW } \\
(\mathrm{g} / \mathrm{L})\end{array}$ & $\begin{array}{c}\text { Parameter to } \\
\text { be } \\
\text { optimized }\end{array}$ \\
\hline \multicolumn{7}{|c|}{ Optimization of loading rate } & $\begin{array}{c}\text { Loading rate } \\
\text { (g/L) }\end{array}$ \\
\hline D-2.1 & $0: 1$ & 00 & 25 & 0 & 0 \\
\hline D-2.2 & $1: 1$ & 25 & 25 & 50 & 50 \\
\hline D-2.3 & $2: 1$ & 50 & 25 & 100 & 100 \\
\hline D-2.4 & $3: 1$ & 75 & 25 & 150 & 150 \\
\hline D-2.5 & $4: 1$ & 100 & 25 & 200 & 200 \\
\hline D-2.6 & $5: 1$ & 125 & 25 & 250 & 250 \\
\hline D-2.7 & $6: 1$ & 150 & 25 & 300 & 300 \\
\hline D-2.8 & $7: 1$ & 175 & 25 & 350 & 350 \\
\hline D-2.9 & $8: 1$ & 200 & 25 & 400 & 400 \\
\hline \multicolumn{7}{|c|}{ Optimization of temperature } & Temperature \\
\hline \multicolumn{7}{|c|}{ C) } \\
\hline D-3.1 & $4: 1$ & 100 & 25 & 200 & 25 \\
\hline D-3.2 & $4: 1$ & 100 & 25 & 200 & 35 \\
\hline D-3.3 & $4: 1$ & 100 & 25 & 200 & 40 \\
\hline D-3.4 & $4: 1$ & 100 & 25 & 200 & 45 \\
\hline D-3.5 & $4: 1$ & 100 & 25 & 200 & 50 \\
\hline \multicolumn{7}{|c|}{ Optimization of alkalinity } & NaOH (\%) \\
\hline D-4.1 & $4: 1$ & 100 & 25 & 200 & 0.5 \\
\hline D-4.2 & $4: 1$ & 100 & 25 & 200 & 1.0 \\
\hline D-4.3 & $4: 1$ & 100 & 25 & 200 & 1.5 \\
\hline D-4.4 & $4: 1$ & 100 & 25 & 200 & 2.0 \\
\hline
\end{tabular}

\subsection{Pilot-scale}

The pilot-scale experiments were operated in semicontinuous mode. According to the lab-scale experiment, the loading rate of $200 \mathrm{~g} / \mathrm{L}$ was carried out in this trial. Subsequently, the total amount of water 31 liters, $6.2 \mathrm{Kg}$ of $\mathrm{KW}$ and $1.55 \mathrm{Kg}$ of $\mathrm{CM}$ were putted into the digester. The agitator was stirred up manually.

\section{RESULTS AND DISCUSSION}

\subsection{Biogas production from $\mathrm{KW}$ and co-digested KW with CM}

Currently, almost all household digesters are using animal manure as feedstock to produce biogas. However, manure has limited availability in many places particularly in urban areas. Therefore, alternative feedstocks need to be developed. Biogas technology have been using mainly in rural area but there is also a plenty of biomass in urban area. The main composition of MSW is KW and it is mostly unused in all cities of Bangladesh. The biogas components and biogas yield depend on a feed material due to the difference of their characteristics. 


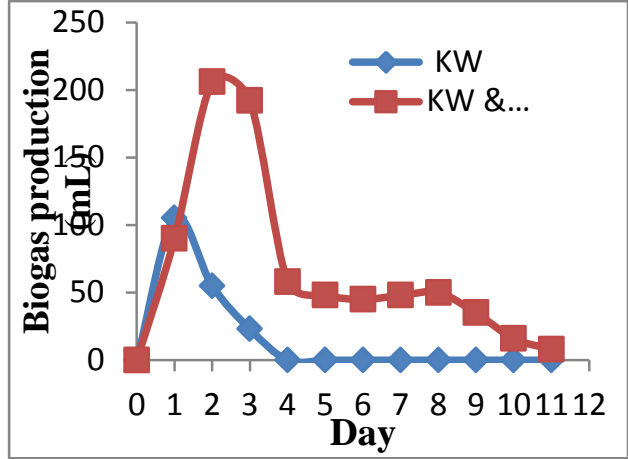

Fig.2: Comparisons on biogas production from $\mathrm{KW}$ co-digested $\mathrm{KW} \& \mathrm{CM}$ at temperature $\left(35^{\circ} \mathrm{C}\right)$ and loading rate $200 \mathrm{~g} / \mathrm{L}$.

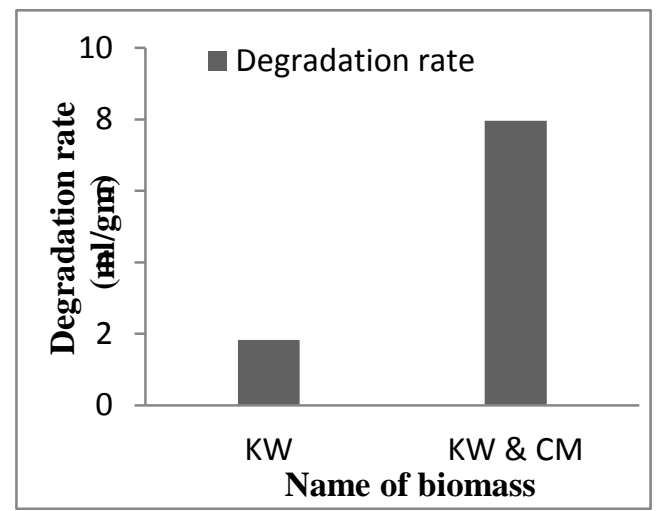

Fig.3: Comparisons on degradation rate $(\mathrm{mL} / \mathrm{g})$ between $\mathrm{KW}$ and co-digested $\mathrm{KW} \& \mathrm{CM}$ at temperature $\left(35^{\circ} \mathrm{C}\right)$ and loading rate $200 \mathrm{~g} / \mathrm{L}$.

Fig.3 shows that the digester D-1.2 (KW and CM) produced more biogas. The degradation rate for digester D-1.2 (KW \& CM) was $7.96 \mathrm{ml} / \mathrm{g}$ and that of $\mathrm{D}-1.1$ was $1.83 \mathrm{~mL} / \mathrm{g}$. $\mathrm{KW}$ contains more readily biodegradable compositions and it is easily converted to biogas but it has low buffer capacity and is easy to acidify [9]. So, the co-digestion of KW and CM would combine together the positive characteristics of the both feed stocks and could potentially bring better digestion performance. The benefits of co-digestion included improved biogas yield, economic advantages derived from the sharing of equipment and easier handled of mixed waste etc [10].

\subsection{Effect of organic loading rate}

One of the main objectives of this study was to determine the performance of the anaerobic digestion process when operated at different loading rates. Therefore, it was important to evaluate process performance in term of biogas production or degradation rates. To optimize the loading rate, several batches were run at ambient temperature and at $35^{\circ} \mathrm{C}$.

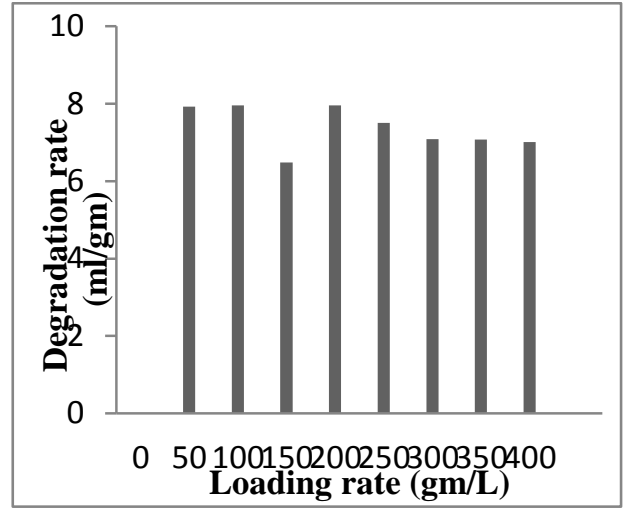

Fig.4: Degradation rate $(\mathrm{mL} / \mathrm{g})$ of $\mathrm{KW}$ at temperature

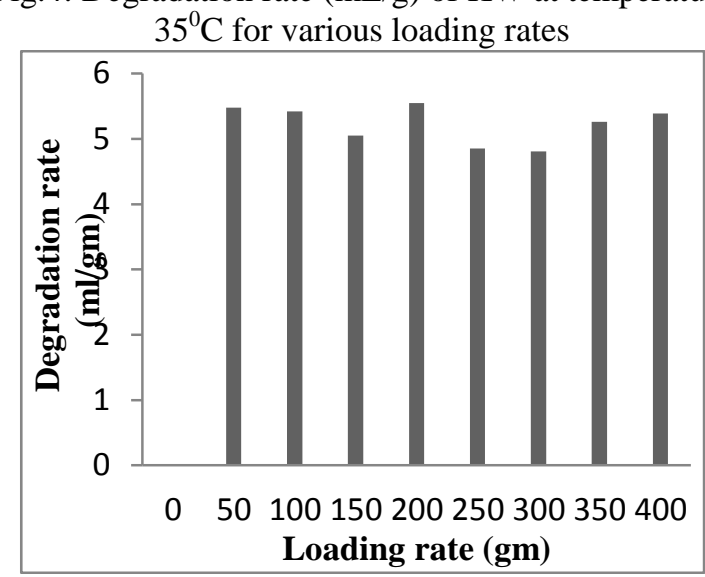

Fig.5: Degradation rate $(\mathrm{mL} / \mathrm{g})$ of $\mathrm{KW}$ at room temperature for various loading rates

Fig.4 represented the biogas production for per gram of KW during the digester's operation at different loading rates. The degradation rates were 7.92, 7.96, 6.48, $7.96,7.5,7.08,7.08 \& 7.00$ respectively corresponding loading rate of $50,100,150,200,250,300,350, \& 400$ $\mathrm{g} / \mathrm{L}$. The degradation rate $\mathrm{KW}$ for $200 \mathrm{~g} / \mathrm{L}$ and $100 \mathrm{~g} / \mathrm{L}$ were same and higher than other loading rate. According to Fig.5, when digestion were carried out at room temperature, the degradation rates were 5.48, $5.42,5.06,5.55,4.84,4.81,5.26$ and $5.39 \mathrm{ml} / \mathrm{g}$ respectively corresponding to same loading rates. In both cases, maximum biogas was produced when the reactor was loaded at the rate of $200 \mathrm{~g} / \mathrm{L}$ of $\mathrm{KW}$. However, manure has limited availability in many places particularly in urban areas. Therefore, it was tried to use maximum amount of $\mathrm{KW}$ and minimum amount of CM.

\subsection{Effect of temperature}

Biogas production from organic substrates is strongly affected by the temperature where anaerobic digestion takes place. The process of organic material anaerobic digestion takes place in three main temperature ranges: from $10-25^{\circ} \mathrm{C}$ (psychrophilic conditions), from 30$37^{\circ} \mathrm{C}$ ( mesophilic conditions) and from $48-55^{\circ} \mathrm{C}$ ( thermophilic conditions). The majority of methanogens (the microorganisms that form methane from organic 
matter) belong to the mesophilic. They grow quickly in this temperature range and exhibit high degrees of conversion. In practice, this has direct implications in the design of biogas plants as they are the most stable operating plants. The stability and growth conditions in the digester at mesophilic conditions make the process more balanced, more resistant to chemicals that inhibit digestion (e.g. ammonia) and capable of treating efficiently a great variety of different types of biomass and waste. The effect of temperature was studied with maintaining same loading rate of $200 \mathrm{~g} / \mathrm{L}$.

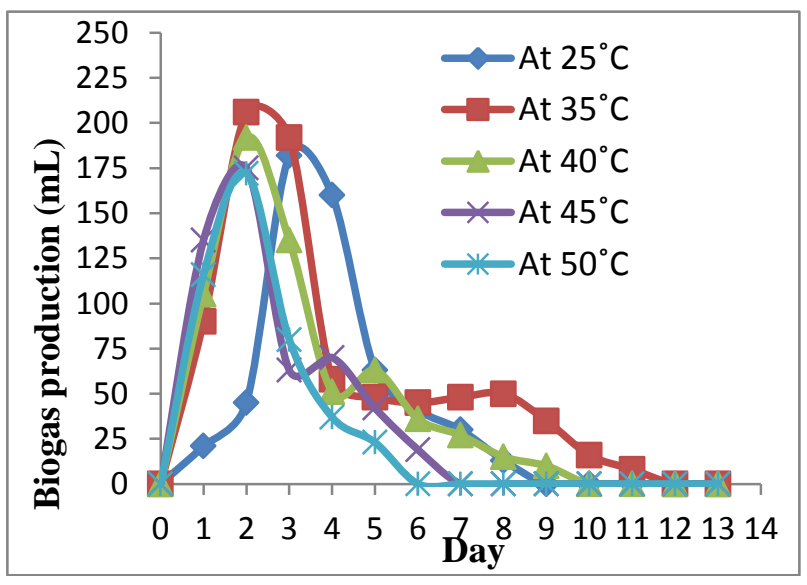

Fig.6: Daily biogas production from KW for loading rate of $200 \mathrm{~g} / \mathrm{L}$ at different temperature.

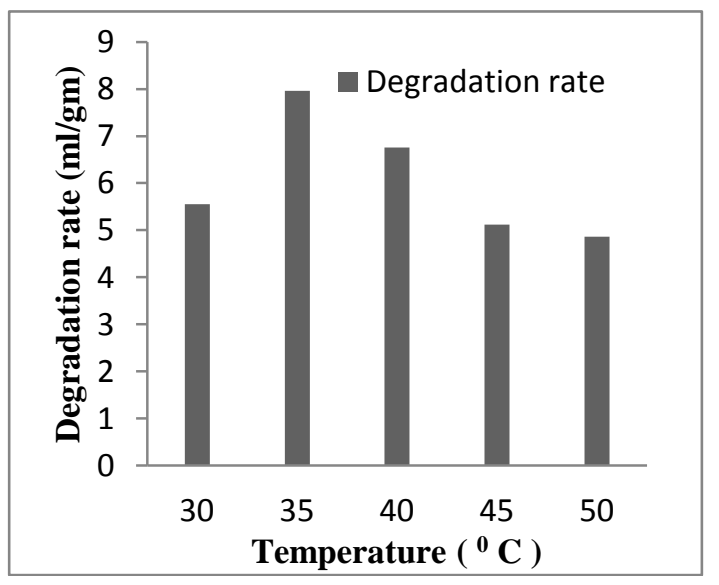

Fig.7: Degradation rate $(\mathrm{mL} / \mathrm{g})$ of $\mathrm{KW}$ for loading rate of $200 \mathrm{~g} / \mathrm{L}$ at different temperature.

When temperature dropped down microbial activity decreased, as a result biogas production or degradation rate was also decreased. On the other hand with the increased of temperature some microorganisms begun to die, once again the production of biogas or degradation rate gradually decreased. From the Fig. 6 and 7 , it was observed that at $35^{\circ} \mathrm{C}$ the biodegradability was high and biogas production was maximum. So, the optimum temperature of biogas production was recorded at $35^{\circ} \mathrm{C}$.

\subsection{Effect of addition of $\mathrm{NaOH}$}

Sodium hydroxide $(\mathrm{NaOH})$ was added with $\mathrm{KW}$ in liquid state at $35^{\circ} \mathrm{C}$ temperature to improve biodegradability and anaerobic biogas production. Four $\mathrm{NaOH}$ doses of $0.5 \%, 1.0 \%, 1.5 \%$, and $2 \%$ on wet matter basis of KW were applied. The raw and $\mathrm{NaOH}$-added KW were then anaerobically digested at loading rate of $200 \mathrm{~g} / \mathrm{L}$.

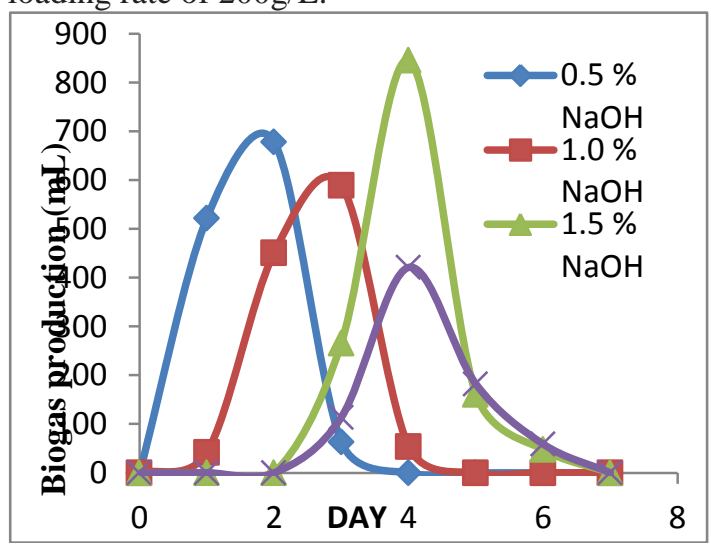

Fig.8: Daily biogas production from $\mathrm{KW}$ with treated by various percentages $\mathrm{NaOH}$ in loading rate of 200 $\mathrm{g} / \mathrm{L}$ at temperature $35^{\circ} \mathrm{C}$.

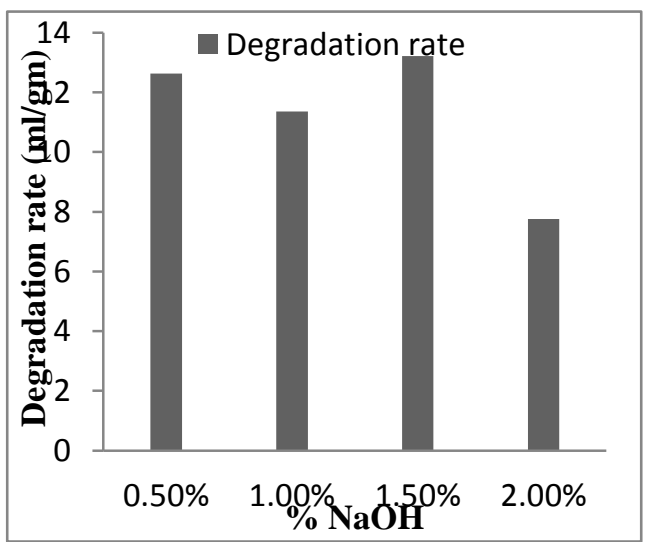

Fig.9: Degradation rate $(\mathrm{mL} / \mathrm{g})$ of $\mathrm{KW}$ treated by different percentages of $\mathrm{NaOH}$ for loading rate of $200 \mathrm{~g} / \mathrm{L}$ at temperature $35^{\circ} \mathrm{C}$.

From Fig.8 and 9, it was detected that for $0.5 \%, 1.0 \%$, $1.5 \%$ and $2.0 \%$ of $\mathrm{NaOH}$ the daily biogas production and degradation rates $(\mathrm{ml} / \mathrm{g})$ were $12.63,11.36,13.21$ and 7.76 respectively. It also found that first two $(0.5 \%$ $\& 1.0 \%$ ) digesters took retention time 6 days and next two $(1.5 \% \& 2.0 \%)$ digesters took retention time 8 days. Although, retention time was longer for $1.5 \%$ of $\mathrm{NaOH}$ but biogas production or degradation rate was also higher than others. Therefore, KW incorporated by $1.5 \% \mathrm{NaOH}$ was optimum in this experiment.

\subsection{Fabrication of portable biogas reactor}

Portable biogas reactor was fabricated and run out in semi-continuous system. The digester volume was about 62 liters. Fig. 10 illustrates the experimental setup. The biogas plant could be constructed over earth 
surface or underground. In Bangladesh, underground biogas plants are mostly used in rural areas. Bangladesh is a flood prone country and large parts of Bangladesh have experience of flood almost every year. So, entering of flood water into the digester will break down its operational capacity. Temperature is another important factor for biogas production. But underground biogas plant has low temperature as a result they can not run with full efficiency to produce biogas. Homogeneous mixing of slurry in the underground digester is not maintained. This digester is not user friendly as it is not carried out one place to another. This type of plant is mostly used in rural areas but not used in urban areas.

The portable biogas plant prepared in our study, easy to carry from one place to another, it will not affected by flood water, temperature also can be maintained at desire condition. Heating system can easily be installed. Even heat can be supplied to the system when it is needed (e.g. in winter). For homogeneous mixing of biomass, agitator can be used in plant. This type of digester or plant can be widely used in both urban and rural areas, and even in multi storied building.

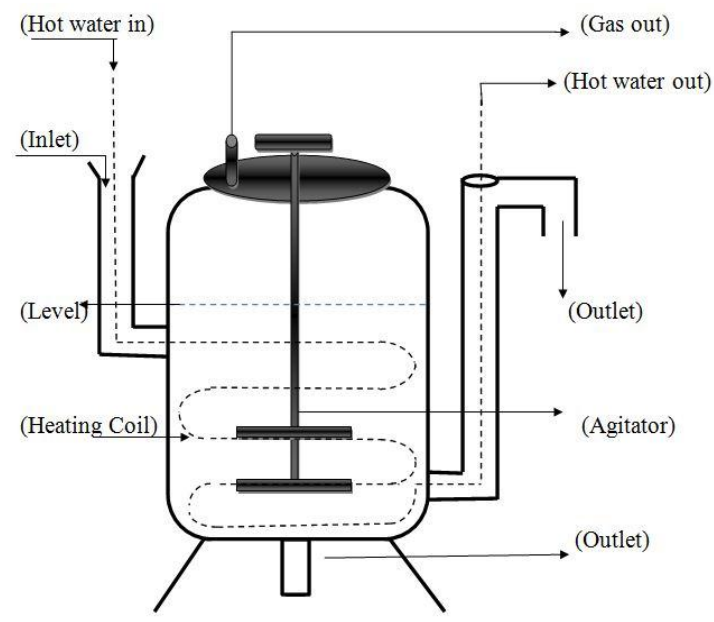

Fig.10: A portable biogas digester set-up.

\section{CONCLUSIONS}

Anaerobic digestion is promising process for reducing the amounts of biodegradable waste in MSW stream and is also an energy producer from renewable resources. Considering the characteristics of the highmoisture solid waste, anaerobic digestion represents a feasible and effective method to convert the waste to biogas fuel. Maximum biogas $(13.21 \mathrm{ml} / \mathrm{g})$ was produced under the conditions- temperature $35^{\circ} \mathrm{C}$, OLR $200 \mathrm{~g} / \mathrm{L}$ and treated with $1.5 \% \mathrm{NaOH}$. When KW was treated by $1.5 \% \mathrm{NaOH}$, it could be achieved $39.74 \%$ more biogas production. Finally a portable biogas digester was fabricated and it was working efficiently under the optimum conditions. The reactor was mainly designed for use in the top of multistoried building. Successful implementation of anaerobic digestion as the method of waste treatment leads to the regional utilization of renewable energy resources, as well as the disposal of high moistening content of KW.

Acknowledgement: The authors are grateful for the financial support of this research from Research Center, Shahjalal University of Science and Technology, Sylhet-3114, Bangladesh.

\section{REFERENCE}

[1] B. Demirel and P. Scherer, Production of methane from sugar beet silage without manure addition by a single-stage anaerobic digestion process, Biomass Bioener., 32 (2008) 203-209.

[2] A. Mshandete, A. Kivaisi, M. Rubindamayugi, and B. Mattiasson, Anaerobic batch codigestion of sisal pulp and fish wastes, Biores. Technol., 95 (2004) 19-24.

[3] M. Murto, L. Björnsson, and B. Mattiasson, Impact of food industrial waste on anaerobic codigestion of sewage sludge and pig manure, $J$. Environ. Manage., 70 (2004) 101-107.

[4] P. Sosnowski, A. Wieczorek, and S. Ledakowicz, Anaerobic co-digestion of sewage sludge and organic fraction of municipal solid wastes, $A d v$. Environ. Res. , 7 ( 2003) 609-616.

[5] K. Umetsu, S. Yamazaki, T. Kishimoto, J. Takahashi, Y. Shibata, Anaerobic co-digestion of dairy manure and sugar beets, Intl. Congr. Ser., 1293 (2006) 307-310.

[6] F. J. Callaghan, D. A. J. Wase, K. Thayanithy, and C. F. Forster, Co-digestion of waste organic solids: batch studies, Biores. Technol., 67 (1999) 117-122.

[7] J. Mata-Alvarez, S. Macé, and P. Llabrés, Anaerobic digestion of organic wastes. An overview of research achievements and perspectives, Biores. Technol., 74 (2000) 3-16.

[8] M .Islam, B. Salam and A. Mohanjan, Generation of biogas from anaerobic digestion of vegetable waste., (ICME-2009), Chittagong, Bangladesh.

[9] R. Li, S. Chen, X. Li, J. S. Lar, Y. He, Anaerobic co-digestion of kitchen Waste with Cattle Manure for Biogas Production, Energy and fuels, 23 (2009) 2225-2228.

[10] P. N. Hobson, S. Bousfield, and R. Summers, Anaerobic digestion of organic matter Critical Reviews in Environmental Control, 74 (1974) 131-191. 